\title{
EUROPEAN BANKING INTEGRATION: IS FOREIGN OWNERSHIP AFFECTING BANKING EFFICIENCY?
}

\author{
José Luis GALLIZO' ${ }^{1}$, Jordi MORENO², Manuel SALVADOR ${ }^{3}$ \\ 1, 2 AEGERN Department, Faculty of Law and Economics, \\ University of Lleida, C/Jaume II, 73, 25008 Lleida, Spain \\ ${ }^{3}$ Department of Statistical Methods, Faculty of Business and Economic Studies, \\ University of Zaragoza, Gran Via 2, 50005 Zaragoza, Spain \\ E-mails:1'gallizo@aegern.udl.cat; 2jmoreno@aegern.udl.cat (corresponding author); \\ salvador@unizar.es
}

Received 17 April 2012; accepted 15 January 2013

\begin{abstract}
The aim of this study is to analyze how European integration and, especially, changes in ownership, has affected banking efficiency in Central and Eastern European countries which have recently experimented this process more intensely. Using a stochastic frontier approach, applied to panel data, we have estimated bank efficiency levels in a sample of 189 banks from 12 countries during the period 2000 to 2008 and we have analyzed the influence of some bank characteristics on these efficiency levels. The results show that European integration has significantly improved the cost efficiency of banks in these countries, but profit efficiency has significantly decreased. We have found very small differences between different ownership types and only a very small impact of foreign ownership on cost efficiency, showing that the entry of foreign ownership is not enough to explain the significant variations in banking efficiency after the accession.
\end{abstract}

Keywords: banking efficiency, European integration, banking ownership, stochastic frontier model, Bayesian inference, new member states.

JEL Classification: G14, G21.

\section{Introduction}

Banking sectors in Central and Eastern European countries have undergone major transformations over the past two decades firstly, as a consequence of the transition from a centrally planned economy to a market economy and, secondly, due to their European integration, characterized by the harmonization of regulation with EU standards, and also, by the access to a common capital market.

After some important changes in political, social and economic models in the early 1990 s, it became clear that it was necessary to introduce major reforms into the banking and financial sectors to provide a basis for the market economy. These processes led to the establishment of specific regulations for banks and other financial intermediaries which permitted their modernization and rapid changes in their ownership structures. 
The study of banking efficiency in these countries has become a recurrent topic in the literature. Furthermore, some authors affirm that it is one of the main factors to spur regional growth (Hasan et al. 2009). Some studies have analyzed the evolution of banking efficiency during the last two decades, when Central and Eastern European countries made important efforts to harmonize their legislations with European standards, although many of these studies have focused on the years before the 2004 enlargement, and with mixed results. For instance, Kasman and Yildirim (2006) analyzed 8 new EU members during the period 1995-2002 without finding improvements in banking efficiency. Mamatzakis et al. (2008) also suggest that the variation in cost efficiency scores among the new member states declines over time. By contrast, Rossi et al. (2004) analyzed 8 new EU members during the period 1995-2002 and found some evidence of improvements in both cost and profit efficiencies. In more recent studies, such as Kosak et al. (2009), which have analyzed more recent periods, there seems to be more coincidence in the results, showing that European integration has contributed to improve banking efficiency in the new EU members, especially on the costs side. However, recent evidence on profit efficiency is much more limited.

As a consequence of the establishment of new regulations for banking sectors, their ownership structures have dramatically changed over the period. Many authors have analyzed the impact that these transformations and, especially, the entry of foreign ownership, have had on banking performance in Central and Eastern European countries (see Table 1). One conclusion is that the entry of foreign capital has provided stability, efficacy and effectiveness to these banking systems (Revoltella 2006) and, as a result, it has improved the competitive environment and has provided more and improved services. However, as we can see in Table 1, when the studies focus on the impact of foreign ownership on individual bank performance, the results are not unanimous and, while some authors found some evidence that foreign banks are, on average, more efficient than their domestic counterparts, others with more recent data have not supported the improved performance of foreign ownership.

In this paper, we analyze the influence that European integration and ownership changes had on banking performance in 12 Central and Eastern European countries ${ }^{1}$. Particularly, given the important changes in banking ownership structures that were a consequence of this process, we analyze whether the effects of this integration on banking efficiency are caused by these ownership changes, especially by the massive entry of foreign capital, or whether we have to look for other causes to explain these effects. To that aim, we have chosen the period 2000-2008 because of its importance, including the latest privatizations of big state-owned banks, the most intensive years of their European integration and the outbreak of the recent international financial crisis.

\footnotetext{
${ }^{1}$ In order to homogenize our sample, we have excluded Cyprus and Malta because of their different political and economic antecedents and their different levels of financial development. We refer to the countries in our sample as Central and Eastern European countries with the Baltic States subsumed into this concept. As a result our sample includes Bulgaria, Croatia, the Czech Republic, Estonia, Hungary, Latvia, Lithuania, Macedonia, Poland, Romania, Slovakia and Slovenia.
} 
J. L. Gallizo et al. European banking integration: is foreign ownership affecting ...

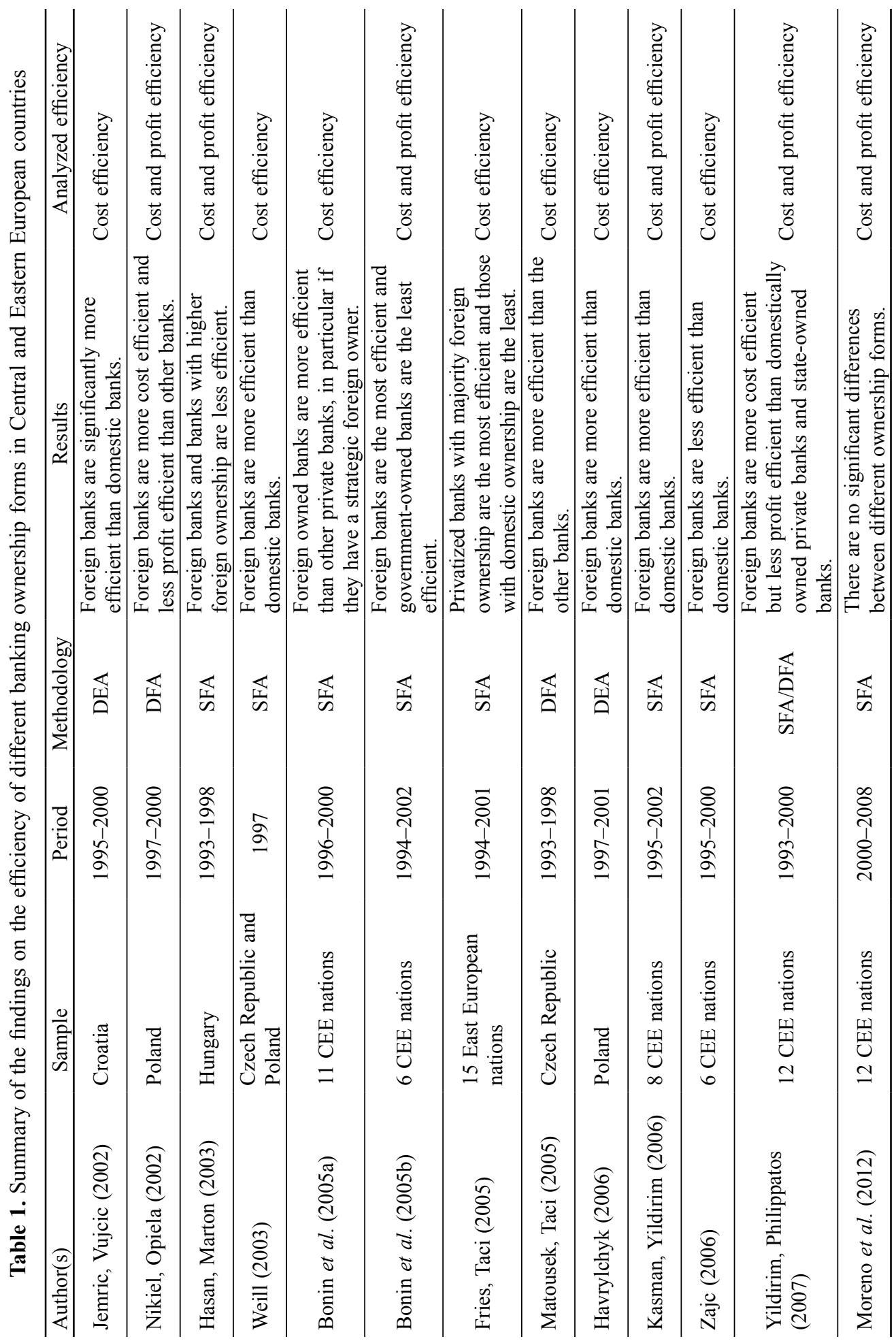


With regard to the influence of European integration, our hypothesis is that it had a positive effect on cost efficiency as a consequence of the adoption of the EU banking standards. For this reason, we hope that cost efficiency levels are higher after the incorporation of new EU members into the European Union. However, we believe that this effect has not been the same in profit efficiency for reasons such as increasing competition, development of non-bank financial sector or the beginning of the economic crisis.

As regards to ownership changes, we not only focus on the simple domestic vs. foreign ownership analysis, widely studied in literature, but also on how different types of ownership influence banking efficiency. As we can see in Table 1, this is a level of analysis that has, so far, received limited research, and where there is no complete evidence of results. Finally, we also analyze the importance of attracting a strategic foreign owner into the ownership structures by estimating the impact of its incorporation on the efficiency levels. In this line of research, our main objective is to provide empirical evidence about whether, as some previous studies focused in the 1990s uphold (Table 1), foreign banks are more efficient than their domestic counterparts or whether, as a consequence of the harmonization of standards caused by European integration these differences have gradually disappeared. These previous studies affirm that foreign ownership was more efficient due to their superior management skills and advanced technology, access to lower costs of funds from the parent company, less subject to domestic credit allocation rules, lack of legacy costs, and differences in clientele, such as a larger share of foreign-owned companies than that of domestically owned companies (Demirguc-Kunt, Huizinga 2000; Nikiel, Opiela 2002). Moreover, it is also argued that foreign banks tend to cherry pick the most profitable opportunities (Fang et al. 2011). However, our hypothesis is that, currently, as a consequence of the adoption of the same rules and participation in the same capital markets, the differences between different ownership forms are decreasing and, therefore, we believe that the type of ownership is no longer a determinant factor of banking efficiency in these countries, and therefore, the responsible authorities have to look for other ways to improve it.

Regarding the main contributions of this paper, as we can see above, some authors have analyzed the implications of European integration and ownership changes on banking efficiency separately; however, none of them has analyzed both factors together in order to know if ownership changes could explain all the variation found in banking efficiency during the European integration. Another relevant contribution of this paper is the use of Bayesian techniques to estimate banking efficiency, whose use is still scarce in this field research despite to be very useful in this kind of problems (Koop et al. 1997; Koop, Steel 2001). Finally, it should be noted that most studies on ownership effects on banking efficiency focus on the transition period (1990s) and the years immediately preceding the 2004 enlargement, while only a few have worked with more recent data including the years immediately following the accession of these countries, a period in which we can analyze the influence of these European milestones. In that sense, our study contributes to fill this gap. 
This paper is organized as follows. In the next section, we describe some of the main changes in Central and Eastern European banking sectors during the last two decades in the framework of European integration Section 2 describes our data set. In Section 3, we outline the methodology used to estimate the banking efficiency levels and, in Section 4, we discuss our results. Finally, the last section provides a conclusion.

\section{Banking transformation in Central and Eastern European countries}

Banking sectors in the Central and Eastern European countries have undergone important changes since, they began a deep transformation in the early 1990s, as a consequence of market liberalization and their European integration. Although these changes did not occur at the same time or with the same intensity in all these countries, we can identify three important stages in the banking restructuring processes that are common to all of them: a first stage of privatizations and mergers, a second stage of consolidation and, subsequently, a third stage of massive entry of foreign ownership (Kosak, Cok 2008).

The first stages of privatizations, mergers and consolidation, led to a significant transfer of bank assets from public to private hands. As a consequence of this process, public ownership, which was the dominant ownership form at the beginning of 1990s, nowadays only maintains a small participation in the banking sectors of almost all these countries (according to EBRD, in 9 of the 12 countries, in 2008, public ownership controlled less than $6 \%$ of total banking assets).

Another very important factor in these reform processes was the massive entry of foreign ownership into the industry, either through the establishment of new branches or through participating in privatization processes, the latter being the most significant since foreign ownership acquired some of the biggest banks. As in the privatization process, there were remarkable differences between the countries with respect to when this entry took place. On the one hand, we can find countries such as Hungary, which were historically more receptive to facilitating this foreign entry even before the political changes. On the other hand, we find the Baltic and Balkan countries, which delayed the entry of foreign ownership into the sector until the mid 1990s.

According to EBRD statistics, between 1995 and 2008 banking assets under foreign control have grown in all countries without exception. In 1995, in 8 of the 12 countries, foreign ownership controlled less than $10 \%$ of total banking assets while, in 2008 , this presence increased dramatically, with 5 countries having more than $90 \%$ of banking assets under foreign control and another 5 countries where this ownership form controlled more than $75 \%$ of total banking assets. Therefore, these results confirm the massive entry of foreign ownership into the industry as one of the most important characteristics of the reform process.

Finally, in order to know the context of each banking sector in 2008, in Table 2 we show the EBRD index banking reform value for each county, which indicates how advanced 
the banking process reforms in all these countries were. Results show that, in 2008, 5 countries had already reached the maximum value of this index ${ }^{2}$.

In short, it is evident that, during the last two decades, the banking sectors in these countries have not only undertaken major reforms but also that these reforms were, in most cases, near their end. For this reason, it is reasonable to think that, in the near future, other neighbouring countries can accelerate the negotiations in order to expedite its entry into the EU and, at the same time, to improve their banking performance and efficiency.

\section{Data}

Balance sheet and income data are taken from the Bureau Van Dijk's BankScope database, which is reviewed monthly, and the last edition used in this study is from October 2011. We have chosen all currently active private commercial banks ${ }^{3}$ in the 12 countries that have undergone major transformations in their banking systems as a consequence of European integration in recent years and for which data were available for all the necessary variables for the estimation of efficiency levels for at least four years between 2000 and 2008. In total, the data set consists of 189 banks with 2,369 observations for cost efficiency and 2,367 observations for profit efficiency.

To analyze the relation between the ownership form and banking efficiency, banks have been divided into four mutually exclusive and collectively exhaustive ownership types: foreign Greenfield banks, new domestic private banks, public banks and privatized banks ${ }^{4}$. To identify the effect of the incorporation of a strategic foreign owner on banking efficiency, we have also considered the date of access of these strategic investors into the ownership structure ${ }^{5}$. In Table 2, we can see the composition of the sample by ownership types and by countries at the end of 2008. It also shows how many banks have a strategic foreign owner.

We can see that new domestic private banks is the biggest category in the sample (43.92\%), while privatized banks and foreign Greenfield banks account for $29.63 \%$ and $23.28 \%$ respectively. Finally public banks are the smallest category (3.17\%). With respect to the presence of a strategic foreign owner, 91 banks in the sample have one

\footnotetext{
${ }^{2}$ This index has been compiled by the EBRD with the primary purpose of assessing the progress of the banking sectors of formerly centrally planned economies. As this indicator quantifies and qualifies the degree of liberalization of the banking industry, it is suitable for an explicit evaluation of the effect of banking sector reforms on the performance of banks (Brissimis et al. 2008). The values of EBRD index range from 1.0 to $4.0+$, with 1.0 indicating a rigid centralized economy and $4.0^{+}$ implying the highest level of reform.

${ }^{3}$ As in Kasman and Yildirim (2006) and Laeven and Levine (2006), in this study, we have only included commercial banks because as Demirguc et al. (2004) argue, focusing on commercial banks improves the comparability of the banks in the sample.

${ }^{4}$ One problem of BankScope is that it only presents the ownership distribution for the last year, without consider the changes in the ownership structure over time. To overcome this limitation, we supplement the data with ownership information from the annual reports of each bank in the sample.

${ }^{5} \mathrm{We}$ consider the presence of a strategic foreign owner in a privatized bank or in a new domestic private bank when more than $50 \%$ of the total stock of shares is held by non-domestic residents.
} 
Table 2. Distribution of banks across bank types by country

\begin{tabular}{lcccccc}
\hline \multirow{2}{*}{ Country } & \multicolumn{7}{c}{ Ownership } & & & \\
\cline { 2 - 7 } & $\begin{array}{c}\text { New domestic } \\
\text { private }\end{array}$ & $\begin{array}{c}\text { Foreign } \\
\text { Greenfield }\end{array}$ & $\begin{array}{c}\text { Public } \\
\text { banks }\end{array}$ & Privatized & $\begin{array}{c}\text { Strategic } \\
\text { owner }\end{array}$ & Total \\
\hline Bulgaria & 8 & 2 & 2 & 2 & 6 & 14 \\
\hline Croatia & 19 & 4 & 0 & 4 & 10 & 27 \\
\hline Czech Republic & 5 & 5 & 2 & 5 & 9 & 17 \\
\hline Estonia & 4 & 0 & 0 & 1 & 4 & 5 \\
\hline Hungary & 2 & 10 & 0 & 6 & 6 & 18 \\
\hline Latvia & 12 & 1 & 1 & 5 & 10 & 19 \\
\hline Lithuania & 4 & 0 & 0 & 4 & 4 & 8 \\
\hline Macedonia & 4 & 1 & 0 & 5 & 5 & 10 \\
\hline Poland & 9 & 8 & 1 & 8 & 14 & 26 \\
\hline Romania & 9 & 7 & 0 & 3 & 11 & 19 \\
\hline Slovakia & 3 & 4 & 0 & 5 & 8 & 12 \\
\hline Slovenia & 4 & 2 & 0 & 8 & 4 & 14 \\
\hline Total & $\mathbf{8 3}$ & $\mathbf{4 4}$ & $\mathbf{6}$ & $\mathbf{5 6}$ & $\mathbf{9 1}$ & $\mathbf{1 8 9}$ \\
\hline
\end{tabular}

\section{Notes:}

1. The data of the first four columns show the number of banks by country and ownership.

2. The column labeled strategic owner shows the number of new private domestic banks and privatized banks with a strategic foreign ownership in their ownership structure.

3. The last column shows the number of banks by country.

4. The last row shows the total number of banks according to its ownership form.

in their ownership structure ${ }^{6}$. This presence implies that, at the end of the period, 135 banks have a wholly or majority foreign ownership (70.9\% of the banks in the sample) ${ }^{7}$.

Croatia, with 27 banks (14.29\%), is the country with the largest number of banks in the sample, followed by Poland (13.76\%), while Estonia, with 5 banks, is the country with the least number of banks $(2.65 \%)$ followed by Lithuania $(4.23 \%)$.

\section{Methodology}

\subsection{Cost and profit efficiency}

To estimate banking efficiency, recent literature has considered two main types of banking efficiency: cost and profit efficiency. Cost efficiency provides a measure of how close a bank's actual cost is to what a best-practice firm's cost would be for producing an identical amount of output under comparable conditions. Profit efficiency measures

\footnotetext{
${ }^{6}$ Only new domestic private and privatized banks can present a strategic foreign owner in their ownership structures.

${ }^{7}$ Foreign Greenfield banks, new domestic private banks with a strategic foreign owner and privatized banks with a strategic foreign owner have a wholly or majority foreign ownership.
} 
the extent to which a firm's profits fall below the profit of the best-practice firm ${ }^{8}$. Due to the difficulty of identifying the output prices, banking efficiency studies have concentrated mostly on cost efficiency measures (Weill, 2003; Fries, Taci 2005; Kosak et al. 2009 , etc.). However, some empirical evidence has shown that profit efficiency is of greater quantitative importance than cost efficiency (see, Rossi et al. 2004; Kasman, Yildirim 2006), suggesting that the most important inefficiency is on the revenue side, either due to the choice of a composition of production that is not the most suitable given the prices of services or to the establishment of a bad pricing policy (Kasman, Yilidrim 2006). Furthermore, the most cost efficient banks are not necessarily the most profit efficient ones and visa-versa (Pasiouras et al. 2009; Casu, Girardone 2004; Guevara, Maudos 2002; Berger, Mester 1997). A pioneer study in this line was Berger et al. (1993), where the authors state that the profit function allows the researcher to pinpoint the sources of inefficiency better because separate estimates of technical and allocative inefficiencies on both, the output and input sides of the firm, may be derived, as well as interactive effects.

For all these reasons, in this paper, we analyze cost and profit efficiency together to achieve a more complete vision of this topic.

\subsection{Bayesian stochastic frontier models}

In order to estimate the cost and profit efficiency, we have used stochastic frontier models ${ }^{9}$. We have used a Bayesian approach that allows us to make exact inferences about the parameters of the model (Koop, Steel 2001) without resorting to the use of asymptotic results of doubtful use in this context (an unbalanced panel with a short number of series with a limited sample size). To that aim, the Bayesian approach uses the posterior distribution of the parameters that is calculated using the Bayes theorem. If this distribution is analytically intractable, it can be calculated using MCMC methods (see, for instance, Robert, Casella 2004).

The Bayesian approach is the basis of some of the most recent and successful applied research (Koop et al. 1999, 2000; Notteboom et al. 2000; Kleit, Terrel 2001; Koop, Steel 2001). In particular, more recent studies have already demonstrated the validity

\footnotetext{
${ }^{8}$ Following Berger and Mester (1997), we can distinguish two profit functions depending on whether or not the existence of market power in the setting of output price is assumed. The standard profit function assumes perfect competition in the markets for outputs and inputs. According to Berger and Mester (1997), the alternative profit function is a closer representation of reality whenever the assumption of perfect competition in the setting of prices is questionable or when there are differences of quality among the individuals of the sample or when output prices are not accurately measured. As Kasman and Yidlirim (2006) argue, since our sample includes a diverse group of countries with different levels of competition, it seems more appropriate to estimate an alternative profit function than a standard profit function for international comparisons. For this reason, we only estimate an alternative profit frontier. This alternative profit function has been employed in many studies of banking efficiency, including Rogers (1998), Berger and Mester (1997), Humphrey and Pulley (1997), Maudos et al. (2002), Bonin et al. (2005a, 2005b), Kasman and Yildirim (2006), and Pasiouras et al. (2009).

${ }^{9}$ The stochastic frontier approach was introduced by Aigner et al. (1977), it was made tractable by Jondrow et al. (1982), and its application to the banking sector was developed by Ferrier and Lovell (1990). Since then the stochastic frontier approach has become one of the most widely used techniques in this field of research (see, for example, Berger, Humphrey 1997; Kumbhakar, Lovell 2000).
} 
and advantages of using Bayesian inference to analyze banking efficiency (Marsh et al. 2003; Kumbhakar, Tsionas 2005; Tecles, Tabak 2010; Assaf et al. 2011). Bayesian analysis of a stochastic frontier function was first proposed by Broeck et al. (1994), and provides the researcher with a set of more flexible models which overcome the need to impose prior sampling distributions on the efficiency term of the composed error term that characterizes conventional stochastic frontier approaches (Murillo-Zamorano 2004). The Bayesian approach presents several advantages over the maximum likelihood method, traditionally used in the literature to estimate these kinds of models. It let include "prior" information about parameters and provides statistical tools to compare non-nested models in terms of their goodness of fit to the data that takes into account the uncertainty associated to the estimation of their parameters. Finally, the Bayesian approach makes it easier to estimate robust hierarchical models to analyze the influence of a set of covariates on the efficiency distribution.

Zhang (2000) compared the performance of Bayesian and maximum likelihood estimation methods in terms of the mean square error criterion, showing the superiority of the former in estimating stochastic frontier models. For more details about the advantages of the Bayesian methodology see Koop and Steel (2001).

In addition, the Bayesian methodology makes it possible analyze the statistic significance of the models and its parameters. We can select the most adequate model by means of Bayesian comparison procedures such as the Bayes factor or alternatively, penalized likelihood criteria such as the BIC criterion or the DIC criterion, which takes into account the parsimony and the goodness of fit of the model to the data. Additionally, we can also analyze the statistic significance of the parameters of the model by means of Bayesian credibility intervals which contains with a given probability, the true value of the parameter and whose validity is subject to the validity of the selected model. The limits of these intervals are calculated from the adequate quantiles of the posterior distribution of the parameters.

\subsubsection{The model}

We have opted for the added value approach (Berger, Humphrey 1992). Following Humphrey and Pulley (1997), we consider that banks provide two main categories of financial services: (1) intermediation and loan services; and (2) payment, liquidity and safekeeping services. Therefore, this study considers deposits as input and output at the same time since they imply creation of value added ${ }^{10}$. Thus, following Dietsch and Lozano-Vivas (2000), Maudos and Pastor (2001), Maudos et al. (2002), Cavallo and Rossi (2002), Carvallo and Kasman (2005), Pasiouras et al. (2009), among others, we have used three outputs: deposits (D), loans (L) and other earning assets (G), and three input prices: price of capital (PC), (ratio of total operating expenses net of personnel expenses to fixed assets), price of funds (PF), (ratio of financial expenses to total deposits) and price of labour (PL), (ratio of total personnel expenses to total assets $)^{11}$.

\footnotetext{
${ }^{10}$ Further discussion on the definition of inputs and outputs variables in Berger and Humphrey (1992), Tortosa-Ausina (2002) or Inklaar and Wang (2013).

${ }^{11}$ We use total assets rather than the number of employers because there are several missing values for the latter. Our approach is consistent with several previous studies including Maudos et al. (2002),
} 
Our dependent variables are the total cost (C) for cost efficiency and the profit before taxes (B) for profit efficiency.

We have used a translog specification ${ }^{12}$ for the model. To account for heterogeneity between countries (different technology, competition...) and years (economic environment, technologic change...), we have included fixed effects for each country and year ${ }^{13}$. So, the minimum cost (or maximum profit) that one bank can reach depends on the country where the bank is established and also depends on the analyzed year. So, if $\mathrm{i}$ denotes the bank and the period, the equation of the model is given by:

$$
\begin{aligned}
& \mathrm{y}_{\text {it }}=\alpha+\beta_{1} \mathrm{~d}_{\text {it }}+\beta_{2} l_{\text {it }}+\beta_{3} \mathrm{~g}_{\text {it }}+\beta_{4} \mathrm{pc}_{\text {it }}+\beta_{5} \mathrm{pf}_{\mathrm{it}}+\beta_{6} \mathrm{pl}_{\text {it }}+{ }_{\text {it }} \beta_{7} \mathrm{~d}_{\text {it }}^{2}+\beta_{8} \mathrm{~d}_{\text {it }} l_{\text {it }}+\beta_{9} \mathrm{~d}_{\text {it }} \mathrm{g}_{\mathrm{it}}+ \\
& \beta_{10} \mathrm{~d}_{\mathrm{it}} \mathrm{pc}_{\mathrm{it}}+\beta_{11} \mathrm{~d}_{\mathrm{it}} \mathrm{pf}_{\mathrm{it}}+\beta_{12} \mathrm{~d}_{\mathrm{it}} \mathrm{pl}_{\mathrm{it}}+\beta_{13} \mathrm{l}_{\mathrm{it}}^{2}+\beta_{14} \mathrm{l}_{\mathrm{it}} \mathrm{g}_{\mathrm{it}}+\beta_{15} \mathrm{l}_{\mathrm{it}} \mathrm{pc}_{\mathrm{it}}+\beta_{16} l_{\mathrm{it}} \mathrm{pf}_{\mathrm{it}}+\beta_{17} l_{\mathrm{it}} \mathrm{pl}_{\mathrm{it}}+ \\
& \beta_{18} \mathrm{~g}_{\text {it }}^{2}+\beta_{19} \mathrm{~g}_{\mathrm{it}} \mathrm{pc}_{\mathrm{it}}+\beta_{20} \mathrm{~g}_{\mathrm{it}} \mathrm{pf}_{\mathrm{it}}+\beta_{21} \mathrm{~g}_{\mathrm{it}} \mathrm{pl}_{\mathrm{it}}+\beta_{22} \mathrm{pc}_{\mathrm{it}}^{2}+\beta_{23} \mathrm{pc}_{\mathrm{it}} \mathrm{pf}_{\mathrm{it}}+\beta_{24} \mathrm{pc}_{\mathrm{it}} \mathrm{pl}_{\mathrm{it}}+ \\
& \beta_{25} \mathrm{pf}_{\mathrm{it}}^{2}+\beta_{26} \mathrm{pf}_{\mathrm{it}} \mathrm{pl}_{\mathrm{it}}+\beta_{27} \mathrm{pl}_{\mathrm{it}}^{2}+\sum_{\mathrm{j}=2}^{12} \beta_{27+\mathrm{j}-1} \mathrm{IP}_{\mathrm{ij}}+\sum_{\mathrm{j}=2}^{9} \beta_{38+\mathrm{j}-1} \mathrm{IT}_{\mathrm{ij}}+\mathrm{u}_{\mathrm{it}}+\mathrm{v}_{\mathrm{it}} \text {, }
\end{aligned}
$$

if $\mathrm{y}_{\mathrm{it}}=\log \left(\mathrm{C}_{\mathrm{it}}\right)$, and:

$$
\begin{aligned}
& \mathrm{y}_{\mathrm{it}}=\alpha+\beta_{1} \mathrm{~d}_{\mathrm{it}}+\beta_{2} l_{\mathrm{it}}+\beta_{3} \mathrm{~g}_{\mathrm{it}}+\beta_{4} \mathrm{pc}_{\mathrm{it}}+\beta_{5} \mathrm{pf}_{\mathrm{it}}+\beta_{6} \mathrm{pl}_{\mathrm{it}}+{ }_{\mathrm{it}} \beta_{7} \mathrm{~d}_{\mathrm{it}}^{2}+\beta_{8} \mathrm{~d}_{\mathrm{it}} l_{\mathrm{it}}+\beta_{9} \mathrm{~d}_{\mathrm{it}} \mathrm{g}_{\mathrm{it}}+ \\
& \beta_{10} \mathrm{~d}_{\mathrm{it}} \mathrm{pc}_{\mathrm{it}}+\beta_{11} \mathrm{~d}_{\mathrm{it}} \mathrm{pf}_{\mathrm{it}}+\beta_{12} \mathrm{~d}_{\mathrm{it}} \mathrm{pl}_{\mathrm{it}}+\beta_{13} l_{\mathrm{it}}^{2}+\beta_{14} l_{\mathrm{it}} \mathrm{g}_{\mathrm{it}}+\beta_{15} l_{\mathrm{it}} \mathrm{pc}_{\mathrm{it}}+\beta_{16} l_{\mathrm{it}} \mathrm{pf}_{\mathrm{it}}+\beta_{17} l_{\mathrm{it}} \mathrm{pl}_{\mathrm{it}}+ \\
& \beta_{18} \mathrm{~g}_{\mathrm{it}}^{2}+\beta_{19} \mathrm{~g}_{\mathrm{it}} \mathrm{pc}_{\mathrm{it}}+\beta_{20} \mathrm{~g}_{\mathrm{it}} \mathrm{pf}_{\mathrm{it}}+\beta_{21} \mathrm{~g}_{\mathrm{it}} \mathrm{pl}_{\mathrm{it}}+\beta_{22} \mathrm{pc}_{\mathrm{it}}^{2}+\beta_{23} \mathrm{pc}_{\mathrm{it}} \mathrm{pf}_{\mathrm{it}}+\beta_{24} \mathrm{pc}_{\mathrm{it}} \mathrm{pl}_{\mathrm{it}}+ \\
& \beta_{25} \mathrm{pf}_{\mathrm{it}}^{2}+\beta_{26} \mathrm{pf}_{\mathrm{it}} \mathrm{pl}_{\mathrm{it}}+\beta_{27} \mathrm{pl}_{\mathrm{it}}^{2}+\sum_{\mathrm{j}=2}^{12} \beta_{27+\mathrm{j}-1} \mathrm{IP}_{\mathrm{ij}}+\sum_{\mathrm{j}=2}^{9} \beta_{38+\mathrm{j}-1} \mathrm{IT}_{\mathrm{ij}}-\mathrm{u}_{\mathrm{it}}+\mathrm{v}_{\mathrm{it}},
\end{aligned}
$$

if $\mathrm{y}_{\mathrm{it}}=\log \left(\mathrm{B}_{\mathrm{it}}\right)$, where $\mathrm{d}_{\mathrm{it}}=\log \left(\mathrm{D}_{\mathrm{it}}\right), \ell_{\mathrm{it}}=\log \left(\mathrm{L}_{\mathrm{it}}\right), \mathrm{g}_{\mathrm{it}}=\log \left(\mathrm{G}_{\mathrm{it}}\right), \mathrm{pc}_{\mathrm{it}}=\log \left(\mathrm{PC}_{\mathrm{it}}\right), \mathrm{pf}_{\mathrm{it}}=$ $\log \left(\mathrm{PF}_{\mathrm{it}}\right), \mathrm{pl}_{\mathrm{it}}=\log \left(\mathrm{PL}_{\mathrm{it}}\right), \mathrm{IP}_{\mathrm{ij}}$ and $\mathrm{IT}_{\mathrm{ij}}$ are indicators of the $\mathrm{j}$-th country and the $\mathrm{j}$-th period, respectively; $u_{i t}$ is the inefficiency term; $v_{i t} \sim \mathrm{N}\left(0, \sigma^{2}{ }_{v}\right)$ is the error and $t \in \mathrm{T}_{\mathrm{i}}$ $\subseteq\{1, \ldots, \mathrm{T}\} ; \mathrm{i}=1, \ldots, \mathrm{N}$, where $\mathrm{T}_{\mathrm{i}}$ is the observation period of the $\mathrm{i}$-th bank and $\mathrm{N}$ is the number of analyzed banks.

\subsubsection{Estimation of the model}

To reduce the potential error of specification, we have estimated two kinds of stochastic frontier model: an exponential model assuming that $\mathrm{u}_{\mathrm{it}} \sim \operatorname{Exp}\left(\lambda_{\mathrm{Z}_{\mathrm{i}, \mathrm{t}}}\right)$ and a truncated

Carvallo and Kasman (2005), Becalli et al. (2006) and Pasiouras et al. (2009).

${ }^{12}$ This function proposed by Christensen et al. (1973) allows us to relax some restrictions associated to Cobb-Douglas function. The translog form does not impose the hypothesis regarding the constant elasticity of the production function or of the elasticity between inputs.

${ }^{13}$ There is a relatively recent literature dealing with bank efficiency in Europe which considers if a common frontier exists or, alternatively, each bank should be compared with its country-peers only. The adoption of the same rules and participation in the same capital market contribute to the existence of a common frontier. However, some studies support the fact that banks in different countries may not operate under the same circumstances due to differences in technology, competition, supervision, etc. (Bos, Schmiedel 2007). 
normal model assuming that con $u_{i, t} \sim N T(0, \infty)\left(\sigma_{Z_{i, t}}^{2}\right)$, where $z_{i, t} \in N$ is a discrete variable that indexes the explanatory characteristics of bank inefficiency $\mathrm{u}_{\mathrm{i}, \mathrm{t}}$. Therefore the mean efficiency level of a bank with characteristics $z_{i, t}$ is given by $E\left[r_{i t} \mid z_{i, t}\right]=$ $E\left[e^{-u_{i, t}} \mid z_{i, t}\right\rfloor$.

Given that we adopt a Bayesian approach, it is necessary to provide a prior distribution of the parameters of the model. In our case, we have used the following non informative distribution:

$$
\alpha \sim \mathrm{N}\left(0, s_{\alpha}^{2}\right) \text { with } \mathrm{s}_{\alpha}^{2}=10^{6}
$$

$\beta_{\mathrm{i}} \sim \mathrm{N}\left(0, s_{\beta}^{2}\right)$ with $s_{\beta}^{2}=10^{6}$ for $\mathrm{i}=1, \ldots, \mathrm{p}$ ( $\mathrm{p}$ number of covariates in the frontier),

$$
\begin{gathered}
\tau_{z_{i, t}}=\frac{1}{\sigma_{z_{i, t}}^{2}} \sim \operatorname{Gamma}(0.001,0.001) \\
\tau_{\mathrm{v}}=\frac{1}{\sigma_{\mathrm{v}}^{2}} \sim \operatorname{Gamma}(0.001,0.001)
\end{gathered}
$$

if the model is normal truncated, and:

$$
\begin{gathered}
\alpha \sim \mathrm{N}\left(0, s_{\alpha}^{2}\right) \text { with } s_{\alpha}^{2}=10^{6}, \\
\beta_{\mathrm{i}} \sim \mathrm{N}\left(0, s_{\beta}^{2}\right) \text { with } s_{\beta}^{2}=10^{6} \text { for } \mathrm{i}=1, \ldots, \mathrm{p}, \\
\lambda_{\mathrm{z}_{i, t}} \sim \operatorname{Gamma}(0.001,0.001), \\
\tau_{\mathrm{v}}=\frac{1}{\sigma_{\mathrm{v}}^{2}} \sim \operatorname{Gamma}(0.001,0.001),
\end{gathered}
$$

if the model is exponential, where we assume that all these distributions are mutually independent.

The estimation of the parameters of the model was carried out from their posterior distribution calculated by using the Bayes theorem. Given that this distribution is not analytically tractable, we use Monte Carlo Markov Chain (MCMC) methods, namely, the Gibbs sampling algorithm described in Griffin and Steel (2007). Using this algorithm, we obtain a sample from the posterior distribution. This sample is used to obtain the value of DIC criterion and to calculate a point estimation and a 95\% Bayesian credibility interval for each parameter using the posterior median and the 2.5 (Q2.5) and 97.5 (Q97.5) quantiles, respectively. The statistical significance of the effects of the covariates $z_{i, t}$ is evaluated by comparing the models with and without the covariates 
according to DIC criterion. Finally, we analyse the existing difference by means of the 95\% Bayesian credibility intervals of the mean efficiency levels $E\left[r_{i, t} \mid z_{i, t}\right]$ and the visual comparison of the boxplot of their posterior distribution.

\section{Results}

Firstly, we have estimated the model parameters for both cost and profit efficiency, using an exponential distribution and a normal truncated distribution, respectively, and without including explanatory variables for the efficiency term $\left(\mathrm{z}_{\mathrm{i}, \mathrm{t}}=1 \forall \mathrm{t} \in \mathrm{T}_{\mathrm{i}} ; \mathrm{i} \in\{1, \ldots\right.$, $\mathrm{N}\}$ ). All the estimation and figures were obtained using the statistical package WINBUGS 4.1.

The estimated mean efficiency for the whole sample is $96.39 \%$ for cost efficiency and $87.48 \%$ for profit efficiency, respectively, using an exponential distribution, and $97.86 \%$ for cost efficiency and $81.04 \%$ for profit efficiency, respectively, using a normal truncated distribution. These results show that, on average, the banks included in the sample have been operating near from the efficiency frontier, especially in relation to costs, where, on average, banks could reduce the inefficiency by $3-4 \%$. These results show that the most important inefficiency is on the revenue side since banks could increase their profits by $12-19 \%$, on average. This greater quantitative importance for profit inefficiency was also noted in previous studies, as Rossi et al. (2004) or Kasman and Yilidirim (2006). Furthermore, in both cases (cost and profits) there are significant country and time effects. To be more specific, with the only exception of Macedonia in the cost frontier, the rest of country effects are significant negatives. Therefore, being equal in all other covariates, Bulgarian banks tend to have higher costs and profits while Macedonian banks tend to have higher costs. With respect to the higher profits of Bulgarian banks this could be attributed to fact that until 2003, still over $70 \%$ of bank assets were invested in government treasuries that had high interest margin (Fang et al. 2011). As regards to the higher costs of Bulgarian and Macedonian banks, it is known that the adoption of European legislation has forced these countries to recognize higher costs in their income statements.

We used the DIC criterion of Spiegelhalter et al. (2002) ${ }^{14}$ to compare the goodness of fit of the exponential and the truncated normal models. As we can see in Table 3, the exponential model showed a better goodness of fit to the data for the estimation of the two types of efficiency.

\footnotetext{
${ }^{14}$ The Deviance Information Criterion (DIC) evaluates the goodness of fit of the model through its out of sample predictive behaviour. It is given by the expression $\bar{D}+p_{D}$ where $\bar{D}$ is the posterior mean of the deviance statistic and quantifies the goodness of fit to data, and $p_{D}=\bar{D}-\hat{D}$ where $\hat{D}$ is the deviance statistic, calculated assuming that the true value of the parameter is equal to its posterior mean, is called the number effective of parameters and quantifies the parsimony of the model. The lower the value of DIC, the better the goodness of fit to the data. For more details, see Koop et al. (1997), Griffin and Steel (2007).
} 


\subsection{Banking efficiency and European integration}

Due to the progressive adoption of EU legislation, which has provided greater stability and competitiveness in Central and Eastern European banking sectors, we expect that European integration contributed to improve cost banking efficiency in these countries. However, due to the increasing competition in the sector and the development of a non-bank financial sector, lower levels of profit efficiency after the bank's country incorporation into the EU are expected.

To analyze how European integration has influenced the banking efficiency levels in the considered countries, we have estimated the mean cost and profit efficiency for the whole sample depending on whether the analyzed period was before or after the incorporation of the country into the EU. To that aim we have taken $z_{i, t}=1$ if $t<$ $t_{i, \text { incorporation }}$ while 2 is a dummy variable that signals if period $t$ is previous or posterior to $t_{i, \text { incorporation }}$ that denotes the year of incorporation into the EU of the country of the i-th bank. Table 4 shows the estimation of the mean efficiency level before and after the incorporation, and Table 5 shows the results of the comparison of model procedure of the exponential and the truncated normal models according to the DIC criterion.

With respect the mean efficiency levels, our results show a different evolution for cost and profit efficiency after the incorporation into the EU. We can see (Table 4) that, independently of the assumption about the distribution of the inefficiency term, cost efficiency tends to increase after the incorporation, while profit efficiency tends to decrease, being both changes statistically significant.

If we compare the models with and without the $\mathrm{z}_{\mathrm{i}, \mathrm{t}}$ covariate (compare Tables 3 and 5), it can be appreciated that models which incorporate the date covariate have a better goodness of fit according to DIC criterion, being the exponential model which shows a better goodness of fit to the data for the estimation of the two types of efficiency.

In order to analyse if this effect is common to all the countries, we have estimated models where $\mathrm{z}_{\mathrm{i}, \mathrm{t}}$ indicates the country of the $\mathrm{i}^{\text {th }}$ and if the period $\mathrm{t}$ is $<\mathrm{t}_{\mathrm{i} \text {,incorporation }}$ or $\geq t_{i, \text { incorporation }}$ (see Table 6).

Regarding cost efficiency, it can be appreciated that, with the sole exception of Hungary, the rest of the countries have increased their cost efficiency after its incorporation into the EU, with the largest improvements corresponding to Latvia, Bulgaria, Romania, Czech Republic and Poland. These results confirm the positive impact of European integration on cost efficiency observed for the whole sample. The result of Hungary is not surprising since their cost efficiency was already very high before its integration in EU. One reason for this high-level is that Hungary was the first country in the area to carry out major reforms in the banking system. In that sense, some studies focused on the previous years before the integration, as Hasan and Marton (2003) pointed out that the early reorganization initiatives, flexible approaches to privatization, and liberal policies towards foreign banks' involvement with the domestic institutions helped build a relatively stable and increasingly efficient banking system. For example, even before the political change, the Hungarian government had been receptive to foreign banking 
Table 3. Comparison of the models which assume an exponential and a truncated normal distribution of the efficiency term (in bold signalled the model with the best goodness of fit to data according to DIC criterion)

\begin{tabular}{lcccc}
\hline \multicolumn{5}{c}{ Cost efficiency } \\
\hline Model & $\overline{\mathbf{D}}$ & $\hat{\mathbf{D}}$ & $\mathrm{p}_{\mathrm{D}}$ & DIC \\
\hline Exponential & -1079.61 & -1189.94 & 110.32 & -969.29 \\
\hline Truncated normal & -1014.11 & -1077.77 & 63.66 & -950.44 \\
\hline \multicolumn{5}{c}{ Profit efficiency } \\
\hline Model & $\overline{\mathbf{D}}$ & $\hat{\mathbf{D}}$ & $\mathrm{p}_{\mathrm{D}}$ & DIC \\
\hline Exponential & -1993.11 & -2665.48 & 672.37 & -1320.74 \\
\hline Truncated normal & -2157.33 & -3056.99 & 899.66 & -1257.67 \\
\hline
\end{tabular}

activity as it allowed three foreign banks to operate in the country from 1985. In addition, Hungary was the first country to shed legacies of the centrally planned economy by privatizing all but one of its major banks by mid-1997 (Bonin et al. 2005b). In summary, our results do not show an increase in cost efficiency for Hungary associated to the European integration because it had already experienced such improvements prior to the accession.

With regard to profits, the existence of a clear common trend in its evolution cannot be appreciated. While some countries have increased their profit efficiency after the integration (Slovakia, Estonia, Latvia or Czech Republic), other countries have decreased their levels (Slovenia, Hungary, Lithuania, Poland, Romania and Bulgaria). These results show that the impact of European integration on profit efficiency is not clear, and it might depend on the country. However, it is noteworthy that, despite the significant improvements observed in cost efficiency, most countries have experienced a decrease in their profit efficiency; in addition, when profit efficiencies tend to increase, these improvements are not significant statistically. Besides, models which assume a common effect for all the countries have better goodness of fit properties (Table 5). All these results suggest that European integration have had a negative impact on the revenue side.

Table 5 shows the results of the comparison of models where we can see that exponential models which distinguish between countries have a better goodness of fit for the cost efficiency, while exponential models which assume a common effect for all the countries have a better goodness of fit for the profit efficiency.

These results confirm the hypothesis that European integration has had a different impact on cost and profit efficiency. On one hand, it is evident the positive effect on cost efficiency where the integration in EU has contributed to improving banking cost efficiency for the whole sample and for almost all countries. This result is in line with some previous studies, which justify this positive impact by the higher concentration in these sectors (Rossi et al. 2004), the higher presence of foreign ownership and greater macroeconomic stability (Fries, Taci 2005), the privatization process (Bonin et al. 2005b) or 
Table 4. Estimated mean bank efficiency before and after the incorporation of the bank's country into the EU

\begin{tabular}{|c|c|c|c|c|c|c|}
\hline & \multicolumn{3}{|c|}{ Cost efficiency } & \multicolumn{3}{|c|}{ Profit efficiency } \\
\hline $\begin{array}{l}\text { Efficiency term } \\
\text { distribution }\end{array}$ & \multicolumn{3}{|c|}{ Exponential distribution } & \multicolumn{3}{|c|}{ Exponential distribution } \\
\hline Mean efficiency & $2.50 \%$ & median & $97.50 \%$ & $2.50 \%$ & median & $97.50 \%$ \\
\hline $\begin{array}{l}\text { Before incorporation into } \\
\text { the EU }\end{array}$ & 0.9253 & 0.9384 & 0.9519 & 0.8712 & 0.8834 & 0.8949 \\
\hline $\begin{array}{l}\text { After incorporation into } \\
\text { the EU }\end{array}$ & 0.9775 & 0.9932 & 0.9991 & 0.8309 & 0.8504 & 0.8687 \\
\hline $\begin{array}{l}\text { Efficiency term } \\
\text { distribution }\end{array}$ & \multicolumn{3}{|c|}{ Normal truncated distribution } & \multicolumn{3}{|c|}{ Normal truncated distribution } \\
\hline Mean efficiency & $2.50 \%$ & median & $97.50 \%$ & $2.50 \%$ & median & $97.50 \%$ \\
\hline $\begin{array}{l}\text { Before incorporation into } \\
\text { the EU }\end{array}$ & 0.9310 & 0.9532 & 0.9785 & 0.8023 & 0.8146 & 0.8267 \\
\hline $\begin{array}{l}\text { After incorporation into } \\
\text { the EU }\end{array}$ & 0.9658 & 0.9798 & 0.9880 & 0.7754 & 0.7946 & 0.8136 \\
\hline
\end{tabular}

Table 5. Comparison of the models that use the date of the bank's country incorporation into the EU as explanatory variable of the inefficiency term distribution (in bold signalled the model with the best goodness of fit to data according to DIC criterion)

\begin{tabular}{|c|c|c|c|c|}
\hline \multicolumn{5}{|c|}{ Cost efficiency } \\
\hline Model & $\overline{\mathbf{D}}$ & $\hat{\mathbf{D}}$ & $\mathrm{p}_{\mathrm{D}}$ & DIC \\
\hline Exponential common effect & -1201.20 & -1370.16 & 168.96 & -1032.24 \\
\hline Normal truncated common effect & -1048.21 & -1143.62 & 95.411 & -952.802 \\
\hline Exponential country effects & -1225.67 & -1361.89 & 136.22 & -1089.46 \\
\hline Normal truncated country effects & -1220.25 & -1416.2 & 195.947 & -1024.31 \\
\hline \multicolumn{5}{|c|}{ Profit efficiency } \\
\hline Model & $\overline{\mathbf{D}}$ & $\hat{\mathbf{D}}$ & $\mathrm{p}_{\mathrm{D}}$ & DIC \\
\hline Exponential common effect & -2083.30 & -2781.73 & 698.43 & -1384.88 \\
\hline Normal truncated common effect & -2257.87 & -3183.80 & 925.92 & -1331.95 \\
\hline Exponential country effects & -1823.04 & -2337.4 & 514.368 & -1308.67 \\
\hline Normal truncated country effects & -1935.23 & -2583.21 & 647.98 & -1287.25 \\
\hline
\end{tabular}

the higher level of competition (Kosak et al. 2009; Fries, Taci 2005). Finally, we think that the strengthening of prudential regulations has also had a prominent role in this evolution of cost efficiency in the new EU members. On the other hand, the effect of the EU integration point to a common negative effect on revenue efficiency causing that the improvements in cost efficiency are not reflected in profit efficiency. Similar results 
Table 6. Estimated mean bank efficiency for the each country before and after its incorporation into the EU

Cost efficiency

\begin{tabular}{|c|c|c|c|c|c|c|}
\hline \multirow[b]{2}{*}{ Country } & \multicolumn{3}{|c|}{ Before EU incorporation } & \multicolumn{3}{|c|}{ After EU incorporation } \\
\hline & $2.50 \%$ & median & $97.50 \%$ & $2.50 \%$ & median & $97.50 \%$ \\
\hline BULGARIA & 0.8748 & 0.9350 & 0.9884 & 0.9406 & 0.9935 & 0.9994 \\
\hline CZECH REPUBLIC & 0.8986 & 0.9461 & 0.9976 & 0.9681 & 0.9952 & 0.9994 \\
\hline CROATIA $^{*}$ & 0.9644 & 0.9940 & 0.9994 & & & \\
\hline SLOVAKIA & 0.9281 & 0.9805 & 0.9992 & 0.9749 & 0.9960 & 0.9995 \\
\hline SLOVENIA & 0.9600 & 0.9935 & 0.9995 & 0.9685 & 0.9950 & 0.9995 \\
\hline ESTONIA & 0.9037 & 0.9828 & 0.9992 & 0.9386 & 0.9936 & 0.9994 \\
\hline HUNGARY & 0.9658 & 0.9948 & 0.9994 & 0.9572 & 0.9936 & 0.9994 \\
\hline LATVIA & 0.8578 & 0.9022 & 0.9337 & 0.9431 & 0.9880 & 0.9993 \\
\hline LITHUANIA & 0.9111 & 0.9795 & 0.9990 & 0.9552 & 0.9946 & 0.9995 \\
\hline MACEDONIA* $^{*}$ & 0.7753 & 0.8320 & 0.8772 & & & \\
\hline POLONIA & 0.9137 & 0.9664 & 0.9987 & 0.9395 & 0.9876 & 0.9995 \\
\hline ROMANIA & 0.9567 & 0.9922 & 0.9991 & 0.9493 & 0.9928 & 0.9994 \\
\hline \multicolumn{7}{|c|}{ Profit efficiency } \\
\hline & \multicolumn{3}{|c|}{ Before EU incorporation } & \multicolumn{3}{|c|}{ After EU incorporation } \\
\hline Country & $2.50 \%$ & median & $97.50 \%$ & $2.50 \%$ & median & $97.50 \%$ \\
\hline BULGARIA & 0.9570 & 0.9930 & 0.9993 & 0.9333 & 0.9923 & 0.9994 \\
\hline CZECH REPUBLIC & 0.7887 & 0.8368 & 0.8756 & 0.8066 & 0.8526 & 0.8901 \\
\hline CROATIA $^{*}$ & 0.9515 & 0.9889 & 0.9991 & & & \\
\hline SLOVAKIA & 0.8860 & 0.9408 & 0.9988 & 0.8861 & 0.9522 & 0.9987 \\
\hline SLOVENIA & 0.7729 & 0.8320 & 0.8766 & 0.7371 & 0.8005 & 0.8515 \\
\hline ESTONIA & 0.9247 & 0.9874 & 0.9992 & 0.9434 & 0.9927 & 0.9994 \\
\hline HUNGARY & 0.8239 & 0.8675 & 0.9028 & 0.7927 & 0.8436 & 0.8842 \\
\hline LATVIA & 0.8298 & 0.8818 & 0.9259 & 0.8831 & 0.9240 & 0.9952 \\
\hline LITHUANIA & 0.9159 & 0.9854 & 0.9991 & 0.8631 & 0.9319 & 0.9976 \\
\hline MACEDONIA $^{*}$ & 0.8539 & 0.9006 & 0.9401 & & & \\
\hline POLONIA & 0.7736 & 0.8249 & 0.8649 & 0.7618 & 0.8075 & 0.8465 \\
\hline ROMANIA & 0.8419 & 0.8760 & 0.9053 & 0.7305 & 0.8318 & 0.8972 \\
\hline
\end{tabular}

*The incorporation of Croatia and Macedonia into the EU was after 2008. 
were reported in previous studies such as Kasman and Yildirim (2006) or Mamatzakis et al. (2010), where there does not seem to be any continuous improvement in profit efficiency over time. As an explanation, Mamatzakis et al. (2010) found a negative association between profit efficiency and the development of a non-banking financial sector. In our opinion, two possible causes explain this negative effect on the profit efficiency: first, the increasing competition in these sectors, caused by the massive entry of foreign banks and the development of a non-banking financial sector, which has limited the revenues for bank. And second, the adoption of regulations which restrict the activities that bank can undertake. In this sense, Pasiouras et al. (2009) pointed out that less regulatory control allows banks to engage in various activities which result in exploitation of economies of scale and generate income from several sources, increasing profit efficiency.

As we have mentioned before, one of the main changes in these banking sectors over the last two decades was the transformation of their ownership structures, first, as a consequence of the privatization process and, subsequently, with the massive entry of foreign capital. There is some consensus in the literature about the positive effect of the first process, but there is more discussion with respect to the presence of foreign ownership, especially when more recent data are analyzed. For this reason, in the next section, we analyze whether these changes in banking ownership structures and, especially, foreign entry, can explain the evolution of cost and profit efficiency during the European integration.

\subsection{Impact of ownership on banking efficiency}

We have estimated the cost and profit efficiency levels for four ownership types: new domestic private banks, foreign greenfield banks, public banks and privatized banks. For this purpose, we take $z_{i, t}=k$ if bank $i$ belonged to group $k$ in period $t$ and 0 otherwise, where each group corresponds to the four ownership types. Table 7 shows the results of the comparison of models. It can be seen that the best performance corresponds to the exponential model for cost efficiency and the normal truncated model for profit efficiency.

The estimated mean cost and profit efficiencies for models with the best goodness of fit properties can be seen in Table 10 and Figures 5 (cost efficiency) and 6 (profit efficiency).

With regard to costs, it can be seen that foreign Greenfield banks tend to be the more efficient in mean, followed closely by public banks and new domestic private banks, without appreciating significant differences among them. However, privatized banks tend to be the least efficient.

Regarding profits, foreign Greenfield banks tend to be the most efficient, followed by new domestic private banks and public banks without significant differences between them. Finally, privatized banks tend to be the least profit efficient ownership form, being in this case the differences with the other groups statistically significant. 
Therefore foreign Greenfield banks tend to be a little more efficient than the other groups for both cost and profit efficiency, a better performance commonly justified by the use of new technologies and modern and more efficient management and operating techniques (Fang et al. 2011; Grigorian, Manole 2002). However, differences with new domestic private banks and public banks are small. This lack of significant differences is becoming common in recent studies with more recent data which compare the efficiency of different ownership forms (Mamatzakis et al. 2008; Moreno et al. 2012). Furthermore, some studies, such as Bonin et al. (2005b), have shown that after privatization banks tend to increase their efficiency (especially when a strategic foreign owner is attracted), so in the future the efficiency of privatized banks will probably increase being more similar to the levels of the other groups. These results support our hypothesis that differences between different ownership forms are decreasing, probably as a consequence of the adoption of the same rules and participation in the same capital markets, and therefore, we believe that the type of ownership will no longer be a determinant factor of banking efficiency in these countries.

It could be surprising, however, the high-level of efficiency showed by public banks and the low-level showed by privatized banks. With respect to public banks, studies focused on the 1990s and early 2000s traditionally associated this ownership form with lower levels of efficiency and a worse performance (Fries, Taci 2005; Bonin et al. 2005b; Barth et al. 2001). However, more recent studies equate its efficiency to the efficiency of other ownership forms (Mamatzakis et al. 2008; Kraft et al. 2006). The main reason for these results is that during 1990s most public banks in these countries had solvency and liquidity problems, and governments decided to privatize them (Bonin, Wachtel 1999; Barisitz 2005). So in recent studies the sample of public banks is mostly composed of a few well-managed banks. Whereas, privatized banks include some of the problematic public banks in the 1990s, whose legacy have been a burden for their efficiency levels in the following years. These facts justify the results obtained.

For further analysis of the effect of ownership on bank efficiency and considering the attraction of a strategic foreign owner, we carried out a new analysis in which we consider the existence of six ownership types combining the ownership type and the presence/ absence of a strategic foreign owner. Thus, the new categories are: new domestic banks without a strategic foreign owner, privatized banks without a strategic foreign owner, new domestic banks with a strategic foreign owner, privatized banks with a strategic foreign owner, public banks and foreign Greenfield banks. For this purpose, we take $\mathrm{z}_{\mathrm{i}, \mathrm{t}}=\mathrm{k}$ if bank $\mathrm{i}$ belonged to group $\mathrm{k}$ in period $\mathrm{t}$ and 0 otherwise.

The results of the comparison of model are presented in Table 7. It can be seen that the exponential model showed a better goodness of fit for cost efficiency and the normal truncated model showed a better fit for profit efficiency. Table 9 and Figures 3 (cost efficiency) and 4 (profit efficiency show the estimation of the mean efficiency levels of each group using the above models. 
Table 7. Comparison of models which use the ownership form as an explanatory covariate of the inefficiency term distribution (in bold signalled the model with the best goodness of fit to data according to DIC criterion)

\begin{tabular}{|c|c|c|c|c|}
\hline \multicolumn{5}{|c|}{ Cost efficiency } \\
\hline Model & $\overline{\mathbf{D}}$ & $\hat{\mathbf{D}}$ & $\mathrm{p}_{\mathrm{D}}$ & DIC \\
\hline $\begin{array}{l}\text { Exponential without strategic foreign } \\
\text { owner }\end{array}$ & -1070.28 & -1160.52 & 90.23 & -980.05 \\
\hline $\begin{array}{l}\text { Normal truncated without strategic } \\
\text { foreign owner }\end{array}$ & -1022.97 & -1103.18 & 80.21 & -942.77 \\
\hline Exponential with strategic foreign owner & -1149.92 & -1274.80 & 124.88 & -1025.04 \\
\hline $\begin{array}{l}\text { Normal truncated with strategic foreign } \\
\text { owner }\end{array}$ & -1036.54 & -1128.75 & 92.214 & -944.32 \\
\hline \multicolumn{5}{|c|}{ Profit efficiency } \\
\hline Model & $\overline{\mathbf{D}}$ & $\hat{\mathbf{D}}$ & $\mathrm{p}_{\mathrm{D}}$ & DIC \\
\hline $\begin{array}{l}\text { Exponential without strategic foreign } \\
\text { owner }\end{array}$ & -1968.54 & -2589.29 & 620.74 & -1347.80 \\
\hline $\begin{array}{l}\text { Normal truncated without strategic } \\
\text { foreign owner }\end{array}$ & -2162.37 & -2960.04 & 797.67 & -1364.70 \\
\hline Exponential with strategic foreign owner & -1998.85 & -2622.10 & 623.25 & -1375.60 \\
\hline $\begin{array}{l}\text { Normal truncated with strategic foreign } \\
\text { owner }\end{array}$ & -2179.13 & -2964.95 & 785.83 & -1393.30 \\
\hline
\end{tabular}

Table 8. Estimated mean bank efficiency according to its type of ownership without distinguishing presence/absence of a strategic foreign owner

\begin{tabular}{lcccccc}
\hline & \multicolumn{3}{c}{ Cost efficiency } & \multicolumn{3}{c}{ Profit efficiency } \\
\hline Efficiency term distribution & \multicolumn{2}{c}{ Exponential distribution } & \multicolumn{2}{c}{ Normal truncated distribution } \\
\hline Mean efficiency & $2.50 \%$ & median & $97.50 \%$ & $2.50 \%$ & median & $97.50 \%$ \\
\hline $\begin{array}{l}\text { New domestic private } \\
\text { banks }\end{array}$ & 0.9583 & 0.9814 & 0.9959 & 0.8418 & 0.8577 & 0.8727 \\
\hline Foreign Greenfield banks & 0.9696 & 0.9934 & 0.9995 & 0.8516 & 0.8704 & 0.8888 \\
\hline Public banks & 0.9569 & 0.9907 & 0.9992 & 0.8050 & 0.8414 & 0.8729 \\
\hline Privatized banks & 0.9419 & 0.9563 & 0.9709 & 0.7355 & 0.7540 & 0.7713 \\
\hline
\end{tabular}

With regard to costs (Table 9 and Fig. 3), new private banks with strategic owner tend to be the most efficient banks, followed by foreign Greenfield banks, public banks and privatized banks with strategic foreign owner. All these ownership forms showed very similar levels of cost efficiency. Privatized banks without strategic foreign owner and new private banks without strategic foreign owner tend to be the least cost efficient banks. Our findings of the greater cost efficiency of foreign-owned banks, either 


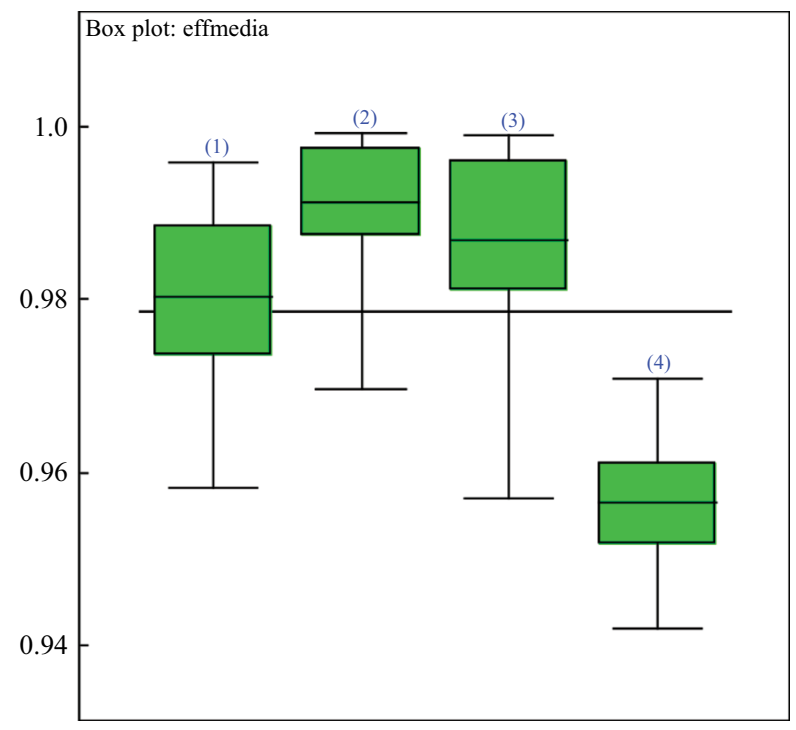

[1]: New domestic banks

[2]: Foreign Greenfield banks

[3]: Public banks

[4]: Privatized banks

Fig. 1. Boxplot of the posterior distribution of the mean cost bank efficiency classified according to its type of ownership without distinguishing presence/ absence of a foreign strategic owner and using the exponential model

privatized or newly established, are consistent with those of Fries and Taci (2005), Grigorian and Manole (2002), Yildirim and Philippatos (2007), and Bonin et al. (2005a). However, our results, which uses more recent data, shows that differences between different groups are not statistically significant, and smaller than in these previous studies. Thus, results show that differences in cost efficiency between different ownership forms have been reduced in recent years.

As for profits (Table 9 and Fig. 4), we observe that new domestic private banks without strategic foreign owner tend to be the most efficient ownership form, followed by foreign Greenfield banks, public banks and new domestic private banks with strategic foreign owner. It is noteworthy that differences between these ownership forms are quite small. However, privatized banks without foreign investors tend to be significantly less efficient than the previous groups, and privatized banks with foreign owner are significantly the least profit efficient ownership type.

If we focus on the effect of attracting a strategic foreign owner to the bank ownership structure, its positive effect is only confirmed for cost efficiency. New private banks without strategic foreign owner tend to be significantly less cost efficient than new private banks with the foreign investor, and the same result is found with privatized banks, being privatized banks with strategic foreign owner more cost efficient than privatized 


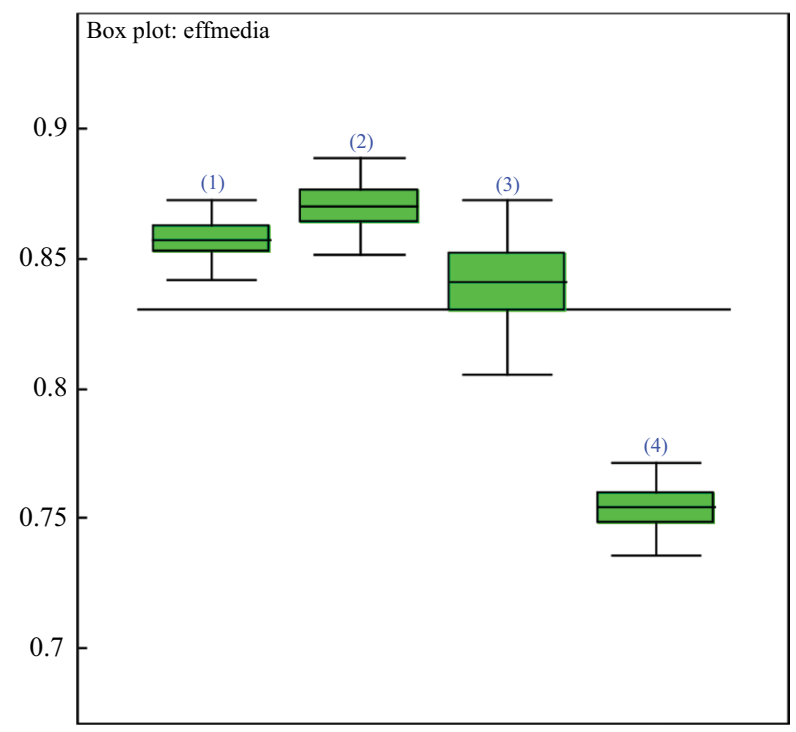

[1]: New domestic banks

[2]: Foreign Greenfield banks

[3]: Public banks

[4]: Privatized banks

Fig. 2. Boxplot of the posterior distribution of the mean profit bank efficiency classified according to its type of ownership without distinguishing presence/ absence of a foreign strategic owner and using the truncated normal model

banks controlled by domestic investors. This positive effect of attracting a strategic foreign owner on cost efficiency has also been reported in previous studies (Bonin et al. 2005b; Fries, Taci 2005).

However, if we focus on profit efficiency, we can see that new private and privatized banks tend to be more efficient when there is no strategic foreign owner. Some previous studies have reached similar results, showing better cost efficiency for foreign ownership and better profit efficiency for domestic banks (Yildirim, Philipatos 2007). Some explanations of this fact are that foreign banks may have more difficulties than domestic banks to deal with a host country's regulations, banking supervision rules, local judiciary in general, and corruption (Lensink et al. 2008). Other studies explain these results by the idiosyncratic features of local customers and service delivery systems (Hasan, Marton 2003). However, our more detailed study shows that this lower profit efficiency is not present in foreign Greenfield banks (which is the second most profit efficient ownership form), and therefore, we cannot generalize for all foreign ownerships. A more likely explanation is that, during the banking restructuring processes in the 1990s, governments adopted some policies to promote the entry of foreign investors in troubled banks, whose legacy has been a burden for their profit efficiencies during the analyzed years. 
Table 9. Estimated mean bank efficiency according to its type of ownership and distinguishing the presence/absence of a strategic foreign owner in the bank

\begin{tabular}{lcccccc}
\hline & \multicolumn{2}{c}{ Cost efficiency } & \multicolumn{3}{c}{ Profit efficiency } \\
\hline Efficiency term distribution & \multicolumn{2}{c}{ Exponential distribution } & Normal truncated distribution \\
\hline Mean efficiency & $2.50 \%$ & median & $97.50 \%$ & $2.50 \%$ & median & $97.50 \%$ \\
\hline $\begin{array}{l}\text { New domestic private banks } \\
\text { without strategic foreign } \\
\text { owner }\end{array}$ & 0.9158 & 0.9359 & 0.9616 & 0.8704 & 0.8892 & 0.9083 \\
\hline $\begin{array}{l}\text { Privatized banks } \\
\text { without strategic foreign }\end{array}$ & 0.9217 & 0.9422 & 0.9590 & 0.7653 & 0.7938 & 0.8197 \\
owner & 0.9690 & 0.9883 & 0.9980 & 0.8157 & 0.8361 & 0.8550 \\
\hline $\begin{array}{l}\text { New domestic private banks } \\
\text { with strategic foreign owner }\end{array}$ & 0.9493 & 0.9718 & 0.9970 & 0.7162 & 0.7379 & 0.7574 \\
\hline $\begin{array}{l}\text { Privatized banks } \\
\text { with strategic foreign owner }\end{array}$ & 0.9509 & 0.9868 & 0.9992 & 0.8131 & 0.8489 & 0.8800 \\
\hline Public banks & 0.9618 & 0.9861 & 0.9991 & 0.8471 & 0.8661 & 0.8851 \\
\hline Foreign Greenfield banks & & & & & & \\
\hline
\end{tabular}

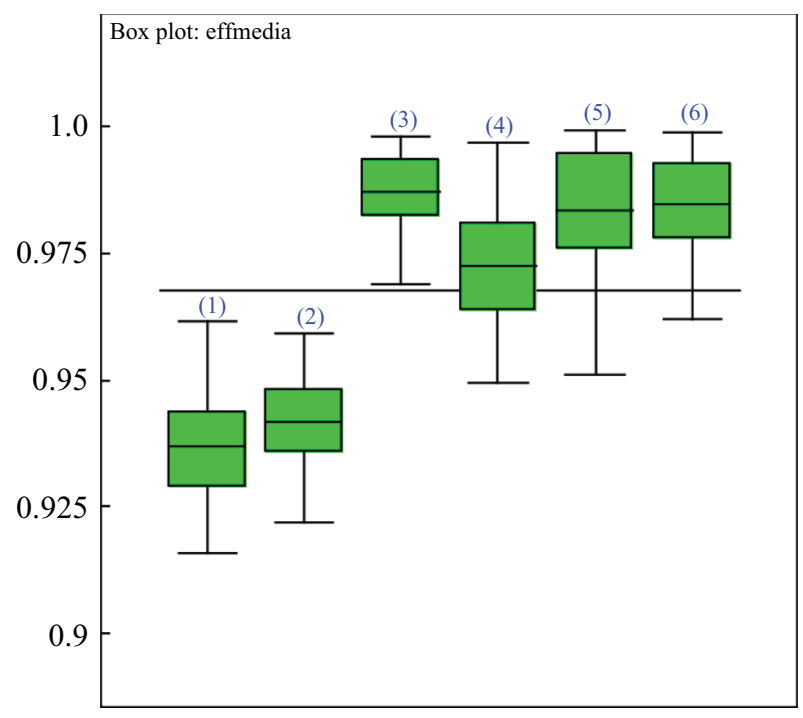

[1]: New domestic private banks without foreign stategic owner

[2]: Privatized banks wihout foreign strategic owner

[3]: New domestic private banks with foreign strategic owner

[4]: Privatized banks with foreign strategic owner

[5]: Public banks

[6]: Foreign Greenfireld banks

Fig. 3. Boxplot of the posterior distribution of the mean cost bank efficiency classified according to its type of ownership, distinguishing the presence/ absence of a foreign strategic owner and using the exponential model 


\section{Conclusions}

In this study we have analyzed the influence of European integration on banking efficiency in some Central and Eastern European countries by analyzing the impact of its EU integration. We have observed that after the integration, banks tend to increase significantly their mean cost efficiency levels, showing the positive impact of European integration on cost efficiency. Conversely, when we analyzed the evolution of mean profit efficiency we noticed the existence of a negative tendency.

Since one of the most visible effects of European integration in Central and Eastern European banking sectors has been the ownership changes, especially the massive entry of foreign ownership, we have also analyzed whether the ownership type, and in particular foreign presence, appears as a key factor to explain these improvements in cost efficiency and the apparent deterioration of profit efficiency. Our results have shown that although foreign Greenfield banks tend to be a little more efficient, differences with new domestic private banks and public banks are not significant, suggesting that these differences have been reduced in recent years, probably as a consequence of the adoption of the same rules and the participation in the same capital market. Only privatized banks tend to be significantly less efficient than the other groups,

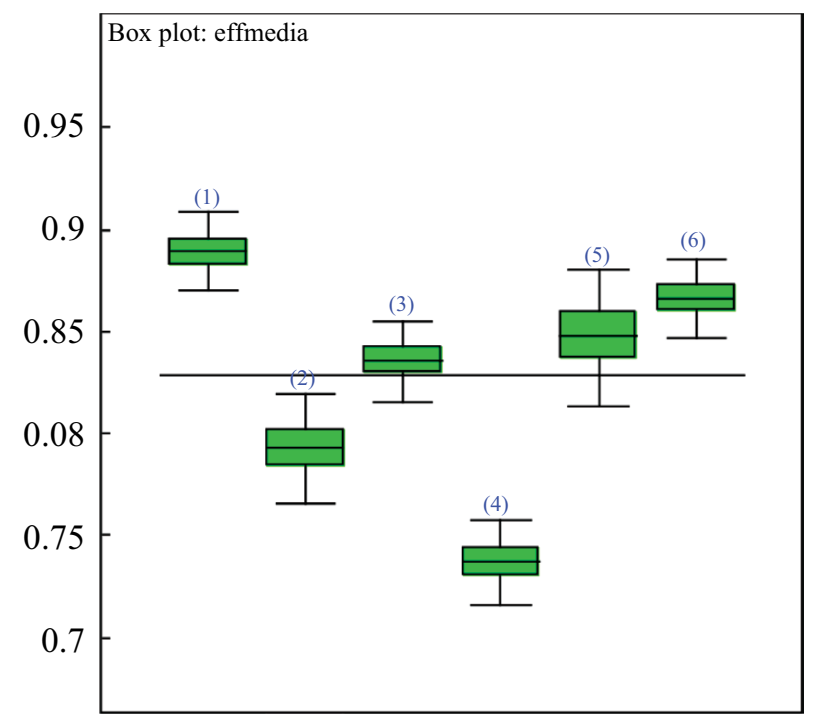

[1]: New domestic private banks without foreign stategic owner

[2]: Privatized banks wihout foreign strategic owner

[3]: New domestic private banks with foreign strategic owner

[4]: Privatized banks with foreign strategic owner

[5]: Public banks

[6]: Foreign Greenfireld banks

Fig. 4. Boxplot of the posterior distribution of the mean profit bank efficiency classified according to its type of ownership distinguishing the presence/absence of a foreign strategic owner and using the truncated normal model 
especially in relation to profits, as a consequence of their legacies. However, some previous studies suggest that banking efficiency tends to increase after privatization, so these differences will be even smaller in the future, and for this reason we think that the ownership form is no longer a determinant factor of banking efficiency in these countries.

When we consider the presence or absence of a strategic foreign owner, we have observed a positive effect on cost efficiency, but not for profit efficiency, where banks seem to be burdened by their legacies. The incorporation of a strategic foreign investor particularly, and foreign ownership in general, could be associated with some higher levels of cost efficiency. However, the differences we found are not enough to explain the significant improvement of cost efficiency detected after the EU integration and, therefore these improvements could have their origins in other factors such as increasing competition or strengthening of prudential regulations. Similar conclusions are reached for profit efficiency, where the high efficiency of foreign Greenfield banks shows that the negative evolution after the EU integration in many countries, is not directly caused by the massive entry of foreign ownership, but it could be due to other causes such as the increasing competition, the development of a non-banking financial sector, or the adoption of regulations that limit banking revenues.

On the basis of the results obtained, several future research directions arise. First, after verifying the improvement of cost banking efficiency in these countries as a consequence of the regulation harmonization with EU standards, it would be interesting to analyze whether there is a convergence process in cost efficiency between the new and the EU-15 members. In addition, the lack of statistical significance for the ownership form suggests that, today, it is no longer a determinant factor of banking efficiency in these countries. So, one future line of research will be to identify which are the determinant factors of bank efficiency in the new EU members today, by analyzing different variables related to banking regulation and supervision, banking structure, financial development and macroeconomic conditions, among others.

Finally, in this study, we have analyzed cost and profit efficiency levels separately. Since costs and profits are closely related, we think that it would be very interesting and more realistic to try to estimate these two efficiencies together.

\section{Acknowledgement}

This paper has benefited from the financial support provided by the Spanish Ministry of Economy and Competitiveness, Research Project ECO2012-35029.

\section{References}

Aigner, D. J.; Lovell, C. A. K.; Schmidt, P. 1977. Formulation and estimation of stochastic frontier models, Journal of Econometrics 6: 21-37. http://dx.doi.org/10.1016/0304-4076(77)90052-5 
Assaf, G.; Barros, C. P.; Matousek, R. 2011. Productivity and efficiency analysis of Shinkin banks: evidence from bootstrap and Bayesian approaches, Journal of Banking and Finance 35(2): 331-342. http://dx.doi.org/10.1016/j.jbankfin.2010.08.017

Barisitz, S. 2005. Banking in Central and Eastern Europe since the turn of the millennium - an overview of structural modernization in ten countries, Focus on European Economic Integration 2/05. Vienna: Oesterreichische Nationalbank, 58-82.

Barth, J.; Caprio, G.; Levine, R. 2001. Banking systems around the globe: do regulation and ownership affect performance and stability?, in Mishkin, F. (Ed.). Prudential supervision: what works and what doesn't. Chicago: University of Chicago Press.

http://dx.doi.org/10.7208/chicago/9780226531939.003.0002

Beccalli, E.; Casu, B.; Girardone, C. 2006. Efficiency and stock performance in European banking, Journal of Business Finance and Accounting 33: 245-262.

http://dx.doi.org/10.2139/ssrn.391668

Berger, A. N.; Hancock, D.; Humphrey, D. B. 1993. Bank efficiency derived from the profit function, Journal of Banking and Finance 17: 317-347.

http://dx.doi.org/10.1016/0378-4266(93)90035-C

Berger, A. N.; Humphrey, D. B. 1992. Measurement and efficiency issues in commercial banking, in output measurement in the service sectors. Z. Griliches (Ed.). Chicago: The University of Chicago Press, 245-479.

Berger, A. N.; Humphrey, D. B. 1997. Efficiency of financial institutions: international survey and directions for future research, European Journal of Operational Research 98: 175-212.

http://dx.doi.org/10.1016/S0377-2217(96)00342-6

Berger, A. N.; Mester, L. J. 1997. Inside the black box: what explains differences in the efficiencies of financial institutions, Journal of Banking and Finance 21: 895-947.

http://dx.doi.org/10.1016/S0378-4266(97)00010-1

Bonin, J. P.; Wachtel, P. 1999. Lessons from bank privatization in Central Europe, Working Paper No. 245. William Davidson Institute.

Bonin, J. P.; Hasan, I.; Wachtel, P. 2005a. Bank performance, efficiency and ownership in transition countries, Journal of Banking and Finance 29: 31-53.

http://dx.doi.org/10.1016/j.jbankfin.2004.06.015

Bonin, J. P.; Hasan, I.; Wachtel, P. 2005b. Privatization matters: bank efficiency in transition countries, Journal of Banking and Finance 29: 2155-2178.

http://dx.doi.org/10.1016/j.jbankfin.2005.03.012

Bos, J. W. B. M; Schmiedel, H. 2007. Is there a single frontier in a single European banking market?, Journal of Banking and Finance 31(7): 2081-2102.

http://dx.doi.org/10.1016/j.jbankfin.2006.12.004

Brissimis, S.; Delis, M. D.; Papanikolau, N. I. 2008. Exploring the nexus between banking sector reform and performance: evidence from newly acceded EU countries, Journal of Banking and Finance 32(12): 2674-2683. http://dx.doi.org/10.1016/j.jbankfin.2008.07.002

Broeck, J. van den; Keep, G.; Osiewalski, J.; Steel, M. F. J. 1994. Stochastic frontier models: a Bayesian perspective, Journal of Econometrics 61: 273-303.

Carvallo, O.; Kasman, A. 2005. Cost efficiency in the Latin American and Caribbean banking systems, Journal of International Financial Markets, Institutions and Money 15: 55-72.

http://dx.doi.org/10.1016/j.intfin.2004.02.002

Casu, B.; Girardone, C. 2004. Financial conglomeration: efficiency, productivity and strategic drive, Applied Financial Economics 14: 687-696. http://dx.doi.org/10.1080/0960310042000243529 
Cavallo, L.; Rossi, S. P. S. 2002. Do environmental variables affect the performance and technical efficiency of European banking systems? A parametric analysis using the stochastic frontier approach, The European Journal of Finance 8: 123-146.

http://dx.doi.org/10.1080/13518470110076277

Christensen, L. R.; Jorgenson, D. W.; Lau, L. J. 1973. Transcendental logarithmic production frontiers, The Review of Economics and Statistics 55: 28-45. http://dx.doi.org/10.2307/1927992

Demirguc-Kunt, A.; Huizinga, H. 2000. Determinants of commercial bank interest margins and profitability: some international evidence, World Bank Economic Review 13: 379-408.

http://dx.doi.org/10.1093/wber/13.2.379

Demirguc-Kunt, A.; Laeven, L.; Levine, R. 2004. Regulations, market structure, institutions, and the cost of financial intermediation, Journal of Money, Credit and Banking 36: 593-622.

Dietsch, M.; Lozano-Vivas, A. 2000. How the environment determines banking efficiency: a comparison between French and Spanish industries, Journal of Banking and Finance 24: 985-1004. http://dx.doi.org/10.1016/S0378-4266(99)00115-6

Fang, Y.; Hasan, I.; Marton, K. 2011. Bank efficiency in transition economies: recent evidence from South-Eastern Europe, Bank of Finland Research Discussion Papers 5/2011: 1-43.

Ferrier, G. D.; Lovell, C. A. K. 1990. Measuring cost efficiency in banking: econometric and linear programming evidence, Journal of Econometrics 46: 229-245.

http://dx.doi.org/10.1016/0304-4076(90)90057-Z

Fries, S.; Taci, A. 2005. Cost efficiency of banks in transition: evidence from 289 banks in 15 post-communist countries, Journal of Banking and Finance 29: 2155-2178.

http://dx.doi.org/10.1016/j.jbankfin.2004.06.016

Griffin, J. E.; Steel, M. F. J. 2007. Bayesian stochastic frontier analysis using WinBUGS, Journal of Productivity Analysis 27: 163-176. http://dx.doi.org/10.1007/s11123-007-0033-y

Grigorian, D. A.; Manole, V. 2002. Determinants of commercial bank performance in transition: an application of data envelopment analysis, IMF Working Papers 02/146. International Monetary Fund.

Guevara, J. F.; Maudos, J. 2002. Inequalities in the efficiency of the banking sectors of the European Union, Applied Economic Letters 9: 541-544. http://dx.doi.org/10.1080/13504850110100867

Hasan, I.; Koetter, M.; Wedow, M. 2009. Regional growth and finance in Europe: is there a quality effect of bank efficiency?, Journal of Banking and Finance 338: 1446-1453.

http://dx.doi.org/10.1016/j.jbankfin.2009.02.018

Hasan, I.; Marton, K. 2003. Development and efficiency of the banking sector in a transitional economy: Hungarian experience, Journal of Banking and Finance 27: 2249-2271.

http://dx.doi.org/10.1016/S0378-4266(02)00328-X

Havrylchyk, O. 2006. Efficiency of the Polish banking industry: foreign versus domestic banks, Journal of Banking and Finance 30: 1975-1996.

http://dx.doi.org/10.1016/j.jbankfin.2005.07.009

Humphrey, D. B.; Pulley, L. B. 1997. Bank's responses to deregulation: profits, technology, and efficiency, Journal of Money, Credit and Banking 29: 73-93.

http://dx.doi.org/10.2307/2953687

Inklaar, R.; Wang, J. C. 2013. Real output of bank services: what counts is what banks do, not what they own. Economica 80(317): 96-117.

http://dx.doi.org/10.1111/j.1468-0335.2012.00942.x

Jemric, I.; Vujcic, B. 2002. Efficiency of banks in Croatia: a DEA approach, Comparative Economic Studies 54(2): 1-25. 
Jondrow, J.; Lovel, C. A. K.; Materov, I. S.; Schmidt, P. 1982. On the estimation of technical inefficiency in the stochastic frontier production function model, Journal of Econometrics 19: 223-238. http://dx.doi.org/10.1016/0304-4076(82)90004-5

Kasman, A.; Yildirim, C. 2006. Cost and profit efficiencies in transition banking: the case of new EU members, Applied Economics 38(9): 1079-1090.

http://dx.doi.org/10.1080/00036840600639022

Kleit, A. N.; Terrell, D. 2001. Measuring potential efficiency gains from deregulation of electricity generation: a Bayesian approach, The Review of Economics and Statistics 83(3): 523-530. http://dx.doi.org/10.1162/00346530152480162

Koop, G.; Osiewalski, J.; Steel, M. F. J. 1997. Bayesian efficiency analysis through individual effects: hospital cost frontier, Journal of Econometrics 76: 77-105.

http://dx.doi.org/10.1016/0304-4076(95)01783-6

Koop, G.; Osiewalski, J.; Steel, M. F. J. 1999. The components of output growth: a stochastic frontier analysis, Oxford Bulletin of Economics and Statistics 61(4): 455-487.

http://dx.doi.org/10.1111/1468-0084.00139

Koop, G.; Osiewalski, J.; Steel, M. F. J. 2000. Modelling the sources of output growth in a panel of countries, Journal of Business and Economic Statistics 18(3): 284-299.

Koop, G.; Steel, M. F. J. 2001. Bayesian analysis of stochastic frontier models, in B. Baltagi (Ed.). A companion to theoretical econometrics. Oxford: Blackwell Publishers, 520-537.

Kosak, M.; Cok, M. 2008. Ownership structure and profitability of the banking sector, Journal of Economics and Business 26(1): 93-122.

Kosak, M.; Zajc, P.; Zoric, J. 2009. Bank efficiency differences in the new EU member states, Baltic Journal of Economics 9(2): 67-90.

Kraft, E.; Hofler, R.; Payne, J. 2006. Privatization, foreign bank entry and bank efficiency in Croatia: a fourier-flexible function stochastic cost frontier analysis, Applied Economies 38: 2075-2088. http://dx.doi.org/10.1080/00036840500427361

Kumbhakar, S.; Lovell, C. A. K. 2000. Stochastic frontier analysis. Cambridge: Cambridge University Press. http://dx.doi.org/10.1017/CBO9781139174411

Kumbhakar, S.; Tsionas, E. 2005. Measuring technical and allocative inefficiency in the translog cost system: a Bayesian approach, Journal of Econometrics 126: 355-384.

http://dx.doi.org/10.1016/j.jeconom.2004.05.006

Laeven, L.; Levine, R. 2006. Corporate governance, regulation, and bank risk taking, Working Paper 11 June, 2006. IMF and Brown University.

Lensink, R; Meesters, A.; Naaborg, I. 2008. Bank efficiency and foreign ownership: do good institutions matter?, Journal of Banking and Finance 32: 834-844.

http://dx.doi.org/10.1016/j.jbankfin.2007.06.001

Mamatzakis, E.; Koutsomanoli-Filippaki, A.; Staikuras, C. 2010. On the determinants of banking efficiency in four new European Union Member States: the impact of structural reforms, MPRA Paper no. 24634.

Mamatzakis, E.; Staikouras, C.; Koutsomanoli-Filippaki, A. 2008. Bank efficiency in the new European Union member states: is there convergence?, International Review of Financial Analysis 17: 1156-1172. http://dx.doi.org/10.1016/j.irfa.2007.11.001

Marsh, T.; Featherstone, A.; Garrett, T. 2003. Input inefficiency in commercial banks: a normalized quadratic input distance approach, Working Paper 2003-036. Federal Reserve Board of St. Louis.

Matousek, R.; Taci, A. 2005. Efficiency in banking: empirical evidence from the Czech Republic, Economic Change and Restructuring 37(3): 225-244. 
Maudos, J.; Pastor, J. 2001. Cost and profit efficiency in baking: an international comparison of Europe, Japan and the USA, Applied Economics Letters 8: 383-387.

http://dx.doi.org/10.1080/135048501750237829

Maudos, J.; Pastor, J. M.; Pérez, F.; Quesada, J. 2002. Cost and profit efficiency in European banks, Journal of International Financial Markets, Institutions and Money 12: 33-58.

http://dx.doi.org/10.1016/S1042-4431(01)00051-8

Moreno, J.; Gallizo, J. L.; Salvador, M. 2012. Bank ownership and efficiency in the new EU members, Modern Economy 3(1): 68-72. http://dx.doi.org/10.4236/me.2012.31010

Murillo-Zamorano, L. R. 2004. Economic efficiency and frontier techniques, Journal of Economic Surveys 18(1): 33-77. http://dx.doi.org/10.1111/j.1467-6419.2004.00215.x

Nikiel, E. M.; Opiela, T. P. 2002. Customer type and bank efficiency in Poland: implications for emerging market banking, Contemporary Economic Policy 20: 55-71.

http://dx.doi.org/10.1093/cep/20.3.255

Notteboom, T.; Coeck, C.; van den Broeck, J. 2000. Measuring and explaining the relative efficiency of container terminals by means of Bayesian stochastic frontier models, International Journal of Maritime Economics 2(2): 83-106.

Pasiouras, F.; Tanna, S.; Zopounidis, C. 2009. The impact of banking regulations on banks' cost and profit efficiency: cross-country evidence, International Review of Financial Analysis 185: 294-302. http://dx.doi.org/10.1016/j.irfa.2009.07.003

Revoltella, D. 2006. The EU banking sector integration, cross border M\&A and implications for the CEE, in Pekao Lecture "Single market, M\&A and European Competitiveness in a Globalized World”, 6 September, 2006, Krynica.

Robert, C. P.; Casella, G. 2004. Monte Carlo statistical methods. 2nd ed. New York: Springer. http://dx.doi.org/10.1007/978-1-4757-4145-2.

Rogers, K. E. 1998. Non-traditional activities and the efficiency of US commercial banks, Journal of Banking and Finance 24: 525-553.

Rossi, S.; Schwaiger, M.; Winkler, G. 2004. Banking efficiency in Central and Eastern Europe, Financial Stability Report 8: 77-91.

Spiegelhalter, D. J.; Best, N. G.; Carlin, B. P.; Van de Linde, A. 2002. Bayesian measures of model complexity and fit with discussion, Journal of the Statistical Royal Society B 64: 583-640. http://dx.doi.org/10.1111/1467-9868.00353

Tecles, P.; Tabak, B. M. 2010. Determinants of bank efficiency: the case of Brasil, Central Bank of Brazil, Working Paper Series no. 210: 1-52.

Tortosa-Ausina, E. 2002. Bank cost efficiency and output specification, Journal of Productivity Analysis 18(3): 199-222. http://dx.doi.org/10.1023/A:1020685526732

Weill, L. 2003. Banking efficiency in transition economies: the role of foreign ownership, Economics of Transition 11(3): 569-592. http://dx.doi.org/10.1111/1468-0351.00155

Yildirim, S. H.; Philippatos, G. 2007. Efficiency of banks: recent evidence from the transition economies of Europe, 1993-2000, The European Journal of Finance 13(2): 123-143.

http://dx.doi.org/10.1080/13518470600763687

Zajc, P. 2006. A comparative study of bank efficiency in central and eastern Europe: the role of foreign ownership, International Finance Review 6: 117-156.

http://dx.doi.org/10.1016/S1569-3767(05)06006-1

Zhang, X. 2000. A Monte Carlo study on the finite simple properties of the GIBBS sampling method for a stochastic frontier model, Journal of Productivity Analysis 14: 71-83.

http://dx.doi.org/10.1023/A:1007895912705 
José Luis GALLIZO is a Professor of Financial Economics and Accounting at the University of Lleida (Spain). He was previously at the Faculty of Economics of the University of Zaragoza (Spain) where he completed his PhD. He has been a visiting researcher in the School of Accounting, Banking and Economics at Bangor University (UK) and visiting lecturer at Paul Sabatier University, Toulouse (France). He is co-author of European Financial Reporting Spain (Routledge) and he has published in Journal of Applied Econometrics, Emerging Markets Finance and Trade, Applied Stochastic Models in Business and Industry, the Journal of International Financial Management and Accounting, the International Journal of Management Science-Omega, European Accounting Review, Journal of Business and Economics, Journal of Forecasting, Journal of the Royal Statistical Society, Review of Accounting and Finance, Global Finance Journal, and several other journals.

Jordi MORENO is a postdoctoral researcher at the University of Lleida (Spain). His main research interests include banking efficiency, family business and co-operative companies. He has some papers published in national and international journals.

Manuel SALVADOR is a Professor in Economic Statistics at the Faculty of Economics and Business Studies of the University of Zaragoza (SPAIN). He received his PhD in Mathematics in 1987. He has published various papers in statistical, operations research, econometrics, financial and business/management magazines such as Journal of Applied Econometrics, Emerging Markets Finance and Trade, Applied Stochastic Models in Business and Industry, Journal of Applied Statistics, Computational Statistics and Data Analysis, Journal of Computational and Graphical Statistics, Operations Research, European Journal of Operations Research, the International Journal of Management Science-Omega, European Accounting Review, Journal of Business and Economics, Journal of Forecasting, Review of Accounting and Finance, Econometric Theory among others. His current research interests include Bayesian inference and spatial and dynamic models in general with applications to economics and business. 